\title{
The Effect of Learning Activity, Teacher Teaching Skills and Achievement Motivation on the Learning Outcomes of Social Studies Lessons
}

\author{
Wahyudi Hermanto, Sudiyono* \\ Universitas PGRI Kanjuruhan Malang \\ Malang, Indonesia \\ *sudiyono.unikama@gmail.com
}

\begin{abstract}
Learning outcomes that meet the educational unit targets are one of the benchmarks for student achievement after learning. The value of learning outcomes is one indicator of the success of the social studies teaching and learning process. This study uses quantitative methods, to determine the effect of active learning, teacher teaching skills and achievement motivation on learning outcomes in social studies subjects. The samples of this research were students of SMP class VIII even semester of the 2018/2019 academic year, both public and private in Lawang District, totaling 303 students. Data collection techniques using questionnaires and documentation. The data analysis used multiple linear regression analysis. Based on the research results, it can be concluded: 1) there is a significant effect of learning activeness on student learning outcomes in social studies subjects, 2) there is no significant effect of teacher teaching skills on student learning outcomes in social studies subjects, 3 ) there is a significant influence on achievement motivation on student learning outcomes in social studies subjects, and 4) there is a simultaneous significant effect of learning activeness, teacher teaching skills, and achievement motivation on student learning outcomes in social studies subject.
\end{abstract}

Keywords-active learning, teacher teaching skills, achievement motivation, learning outcomes

\section{INTRODUCTION}

High learning achievement is the hope that every student wants to achieve in learning. There are many factors that are thought to contribute to the acquisition of student learning outcomes, both internal and external. The teacher is a figure who has a lot of influence on the achievement of student learning outcomes, because the teacher is the party who provides a lot of knowledge, experience, and skills. The application of didactic situation through its design by teacher during the classroom teaching and learning is expected to be able to develop students' potentials so that they can construct their own targeted knowledge through a series of abstraction process. The important elements on which teachers build their professional identity is the role their attribute to themselves [1]. While teacher knowledge is certainly a component of teacher professionalism, professional competence involves more than just knowledge. Skills, attitudes, and motivational variables also contribute to the mastery of teaching and learning [2].

Student learning activeness is important in the teaching and learning process. Because with the activeness of the learning process students will get valuable benefits. One of the problems that arise in the learning process is the low activity of students when participating in the teaching and learning process. Student activeness can be in the form of behavior and enthusiasm that appears in the learning process. The learning activities also may influence students' physical activity levels [3]. Role-play is more effective than discussion on students' speaking skill for students who have low learning motivation at the eleventh grade [4]. Activeness is a behavior that is driven by a willingness to learn because of a goal to be achieved so that in learning activities, students are required to always be active in processing and processing their learning acquisition [5].

The success in the learning process can be measured by the number of students who are active and master the subject matter. The more students who are active and master the material, the more students will be able to achieve success in learning. If students do not instill an active attitude during the teaching and learning process, students will find it difficult to follow the lesson. Activity based teaching helps them to construct their knowledge [6]. The interactivity amid the students is the key agent for successful learning. Interactive resources or environment are helpful to learners because these resources can be accessed at any time and as many times as the learner chooses [7]. Student learning activeness is a learning process that emphasizes student activeness in the class physically, mentally, intellectually and emotionally in order to gain learning achievement [8].

The success of students in obtaining satisfactory grades cannot be separated from the teaching skills of the teacher so that it can create a pleasant learning atmosphere and can make students easy to understand the lessons delivered. The use of good learning strategies is highly dependent on the teaching skills of the teacher in using learning methods, techniques and tactics to enable effective and efficient learning. 
Teaching skills are skills that teachers must have to transfer knowledge, skills, attitudes, and values to students in the learning process [9]. The basic teaching skill is decision making. What distinguishes the exceptional teacher from his or her colleagues is not the ability to ask, say, a higher-order question, but the ability to decide when to ask such a question [10]. This decision-making process is examined using decision theory. Viewed from the decision theory perspective, a teacher has a number of alternative acts from which to choose. The choice may depend, for example, upon the teacher's subjective estimation of a student's understanding of some material and the usefulness of various alternatives in increasing that understanding.

Motivation is one of the important things for students in the learning process to achieve achievement, because motivation will provide enthusiasm, direction and persistence [11]. Achievement motivation is the driving force that enables a person to succeed in achieving what he desires. A person who has high achievement motivation tends to always try to achieve what he wants despite experiencing obstacles and difficulties. Students' motivation in the learning process can be seen from their behavior in learning, students who have high motivation to learn diligently working on the task, resilient face of adversity, show interest in a variety of problems, prefer to work independently, and not get bored in doing the task. Achievement motivation refers to efforts to be competent in struggling activities [12]. Motivation to act is assumed to produce the learning results because of the desire to fulfill needs [13].

\section{MethodS}

The purpose of this study was to analyze the effect of teacher teaching skills on learning activities and student achievement motivation. The research subjects were 303 junior high school students who were taken randomly from a population of 1483 in Lawang District, Malang Regency, Indonesia. The research instrument used was a self-made questionnaire, and validated by content and empirical validity using Cronbach's alpha.

Data analysis techniques include: 1) $t$ test is used to determine the effect of independent variables individually or partially on the dependent variable (dependent), 2) Multiple linear regression analysis is used to determine the effect of learning activeness, teacher teaching skills, and achievement motivation on social studies learning outcomes. As a prerequisite for multiple regression analysis, a classic assumption test is required, including: 1) data normality test, 2) heteroscedasticity test, 3) multicollinearity test, 4) autocorrelation test.

\section{RESEARCH RESULTS}

Based on the results of the classic assumption test that the data is suitable for multiple linear regression tests to determine the magnitude of the relationship between the independent variables and the dependent variable in the form of multiple linear regression equations in Table 1.

TABLE I. MULTIPLE LiNEAR REgRESSION TEST OUTPUT

\begin{tabular}{|c|l|c|c|c|c|}
\hline \multicolumn{2}{|c|}{ Model } & \multicolumn{2}{c|}{$\begin{array}{c}\text { Unstandardized } \\
\text { Coefficients }\end{array}$} & \multirow{2}{*}{ T } & \multirow{2}{*}{ Sig. } \\
\cline { 3 - 4 } \multicolumn{2}{|c|}{} & $\boldsymbol{B}$ & Std. Error & & \\
\hline \multirow{3}{*}{1} & (Constant) & 19.273 & 1.326 & 14.538 & .000 \\
\cline { 2 - 5 } & SumX1 & .987 & .026 & 38.219 & .000 \\
\cline { 2 - 5 } & SumX2 & .043 & .026 & 1.678 & .094 \\
\cline { 2 - 4 } & SumX3 & .065 & .024 & 2.727 & .007 \\
\hline
\end{tabular}

In Table 1 we can see that $\mathrm{Y}=19.273+0.987 \mathrm{X} 1+0.043$ $\mathrm{X} 2+0.065 \mathrm{X} 3$. This equation shows the following: 1) $\mathrm{A}$ Constanta of 19,273 indicates the magnitude of the increase in the learning outcome variable is 19,273 if learning activeness (X1), teacher teaching skills (X2), and achievement motivation (X3) are 0 (zero), 2) The regression coefficient of learning activeness (X1) is 0.987 indicating the magnitude of the correlation between learning activeness and learning outcomes, the regression coefficient is positive which means learning activeness is positively correlated (unidirectional) means that learning activeness causes an increase in learning outcomes of 0.987 and vice versa, 3) The regression coefficient of teacher teaching skills (X2) of 0.043 indicates the magnitude of the correlation between teacher teaching skills and learning outcomes, the regression coefficient is positive which means that teacher teaching skills are positively correlated (unidirectional), meaning that teacher teaching skills lead to an increase in learning outcomes by 0.043 and vice versa, 4) Learning motivation regression coefficient (X3 ) of 0.065 indicating The magnitude of the correlation between achievement motivation and learning outcomes, the regression coefficient is positive, which means that the learning environment is positively correlated (unidirectional), meaning that achievement motivation causes an increase in learning outcomes by 0.065 and vice versa. Table 2 shows the correlation coefficient and determination.

TABLE II. CORRELATION COEFFICIENT AND DETERMINATION

\begin{tabular}{|c|c|c|c|c|}
\hline Model & R & R Square & $\begin{array}{c}\text { Adjusted R } \\
\text { Square }\end{array}$ & $\begin{array}{c}\text { Std. Error of the } \\
\text { Estimate }\end{array}$ \\
\hline 1 & $.942^{\mathrm{a}}$ & .888 & .887 & 1.79217 \\
\hline
\end{tabular}

In Table 2, coefficient of multiple correlation $(\mathrm{R})$ shows the magnitude of the relationship between the independent variables of learning activeness (X1), teacher teaching skills (X2), and achievement motivation (X3) together with the learning outcome variable (Y). The value of the correlation coefficient of 0.942 close to 1 means that the independent variables jointly have a relationship with the dependent variable. 
The value of the coefficient of determination ( $\mathrm{R}$ Square) shows the magnitude of the contribution of all independent variables of learning activeness (X1), teacher teaching skills (X2), and achievement motivation (X3) together on the dependent variable learning outcomes (Y), so R Square 0.888 has meaning that the independent variable is able to contribute $88.8 \%$ to the change in the dependent variable, thus the remaining $11.2 \%$ is determined by other variables not examined.

Hypothesis testing from the results of data processing testing the partial regression coefficient ( $\mathrm{t}$ statistical test) is as follows: 1) Testing the effect of learning activeness (X1) on learning outcomes $(\mathrm{Y})$, based on the results of the analysis, the value of tcount $=38.219$ while $\mathrm{t}$ table $=1.9679$ or $\mathrm{t}$ count $>$ ttable with sig. 0.000 smaller 0.05 , then Ho is rejected (Ha accepted) means that learning activeness (X1) has a significant effect on student learning outcomes (Y), 2) Testing the effect of teacher teaching skills (X2) on learning outcomes (Y). obtained tcount $=1.678$ while ttable $=1.9679$ or $\mathrm{t}$ count $<\mathrm{t}$ table with sig. 0.094 is greater than 0.05 , then Ho is accepted (Ha is rejected) means that teacher teaching skills (X2) do not have a significant effect on student learning outcomes (Y), 3) Testing the effect of achievement motivation (X3) on learning outcomes (Y) based on the results of the analysis obtained the value of $\mathrm{t}=2.727$ while $\mathrm{t}$ table $=1.9679$ or $\mathrm{t}$ count $>\mathrm{t}$ table with a sig. 0.007 is smaller than 0.05 , so Ho is rejected (Ha accepted) means that achievement motivation (X3) has a significant effect on student learning outcomes (Y). Table 3 shows the simultaneous test.

TABLE III. SIMUltaneOUS TEST (F TEST)

\begin{tabular}{|l|l|c|c|c|c|c|}
\hline \multicolumn{2}{|c|}{ Model } & $\begin{array}{c}\text { Sum of } \\
\text { Squares }\end{array}$ & Df & $\begin{array}{c}\text { Mean } \\
\text { Square }\end{array}$ & F & Sig. \\
\hline \multirow{2}{*}{1} & Regression & 7597.417 & 3 & 2532.472 & 788.470 & $.000^{\mathrm{b}}$ \\
\cline { 2 - 7 } & Residual & 960.352 & 299 & 3.212 & & \\
\cline { 2 - 7 } & Total & 8557.769 & 302 & & & \\
\hline
\end{tabular}

In Table 3, the regression coefficients (F Test) hypothesis testing is done by comparing the $\alpha$ value at significance. The research hypothesis is accepted if sig $<0.05$, based on table 3 , the sig value is obtained. $0.000<0.05$ then Ho is rejected (Ha accepted) means that learning activeness, teacher teaching skills, and achievement motivation (simultaneously) have a significant effect on student learning outcomes.

\section{DISCUSSION}

The effect of learning activeness on student learning outcomes is known to have a positive and significant influence between learning activeness on student learning outcomes, with a significant value of 0.000 and a contribution of 0.987 . The effect of these two variables is positive, meaning that the more active student learning, the higher student learning outcomes, and vice versa. Seeing the results of this study, it is hoped that teachers or parents can help students in creating a learning atmosphere that activates their learning, this is considered very important, because it can help students improve their learning outcomes. The type of learning activity offered in physical education may influence students' motivational beliefs, physical activity participation and effort/persistence in class [3].

The effect of teacher teaching skills on student learning outcomes is known to have no significant effect on teacher teaching skills on student learning outcomes. Because these two variables do not have a significant effect, this is because the majority of students do not know and understand the assessment of teacher teaching skills.

The influence of achievement motivation on student learning outcomes is known to have a positive and significant influence on achievement motivation on student learning outcomes, with a significant value of 0.007 and has a contribution of 0.065 in improving student learning outcomes. The influence of these two variables is because the direction is positive, meaning that, the more student achievement motivation increases, the student learning outcomes will increase, and vice versa. Seeing the results of these studies, it is hoped that the student learning environment can increase student achievement motivation both intrinsic and extrinsic, this is considered very important, because it can help students improve their learning outcomes. This study linier with research of Hasan and Sarkar [14], research by Bakar [15] concluded that a positive correlation between Achievement motivation and academic achievement.

Motivation shows encouragement and efforts to meet or satisfy a need or to achieve a goal [16]. Motivation is usually defined as something that energizes and directs behavior. Of course, this is a general definition, a definition that can be applied to many factors that influence behavior. All behaviors are motivated, even the behavior of students looking out of the window and avoiding assignments. Students' willingness to learn is the result of many factors. Starting from the student's personality and the ability of students to complete school assignments, the rewards they have learned, the learning situation encourages students to learn and so on.

The effect of active learning, teacher teaching skills, and achievement motivation on student learning outcomes, it is known that there is a positive and significant influence simultaneously or simultaneously learning activeness, teacher teaching skills, and achievement motivation on student learning outcomes, as indicated by the value a significant amount of 0.000 , which means that, the higher the three independent variables, the higher the student learning outcomes. Likewise, the decreasing of the independent variable, the lower the learning outcomes will be.

\section{CONCLUSION}

Based on the research results it can be concluded as follows: 1) There is a significant effect of learning activeness on learning outcomes. Based on the results of the t test whose data are presented in table 1 , the value of $t$ count $=38.219$ with a sig value is obtained. 0.000 is smaller than 0.05 , which means 
that the $t$ value is strong enough to reject Ho, or it can be stated that there is a significant difference in student learning outcomes between students with "high" learning activeness and students with low learning activeness. Thus it can be stated that there is an effect of active learning on student learning outcomes, 2) There is no significant effect of teacher teaching skills on learning outcomes. Based on the results of the t test presented in table 1 , the results obtained by the value of $t=$ 1.678 while $\mathrm{t}$ table $=1.9679$ with a sig. 0.094 is greater than 0.05 . The coefficient $t$ calculated under the $t$ table with a sig greater than 0.05 indicates that the value $t$ is not strong enough to reject Ho. This test means that teacher teaching skills have no effect on student learning outcomes, 3) There is a significant effect of achievement motivation on learning outcomes. Based on table 1 , it is known that there is a significant influence of achievement motivation on student learning outcomes, with a significant value of 0.007 and has a contribution of 0.065 in improving student learning outcomes, 4) There is a significant influence on student learning activeness, teacher teaching skills and achievement motivation together on learning outcomes. The effect of active learning, teacher teaching skills, and achievement motivation on student learning outcomes it is known that there is a positive and significant influence simultaneously or simultaneously learning activeness, teacher teaching skills, and achievement motivation on student learning outcomes, which is indicated by a significant value of 0.000 , which means that the three independent variables are increasing, and the student learning outcomes will also increase. Likewise, the decreasing of the independent variable, the lower the learning outcomes will be.

\section{REFERENCES}

[1] D. Makovec, "The teacher's role and professional development," (IJCRSEE) International Joirnal of Cognitive Research In Science, Engineering and Education, vol. 6, 2018.
[2] S. Guerriero, "Teachers' pedagogical knowledge and the teaching profession," Teaching and Teacher Education, vol. 2, pp. 7, 2014.

[3] Z. Gao, H.Y. Lee, P. Xiang, and M. Kosma, "Effect of Learning Activity on Students' Motivation, Physical Activity Levels and Effort/Persistence," ICHPER-SD Journal of Research, vol. 6, pp. 27-33, 2011.

[4] U.B. Kamil, "The effect of teaching methods and learning motivations ono sudents' speaking skill," Jurnal Pendidikan UNSIKA. vol 5, 2017.

[5] E. Mulyasa, Standar Kompetensi dan Sertifikasi Guru. Bandung: PT. Remaja. Rosdakarya, 2007.

[6] I. Shah and T. Rahat, Effect of activity based teaching method science, 2014.

[7] H.C. Celik, "The effect of activity based learning on sixth grade students' achiement and attitudes towards mathematics activities," Eurasia Journal of Mathematics, Science and Technology Education, vol.14, pp. 1963-1977, 2018.

[8] O. Hamalik, Proses Belajar Mengajar. Jakarta: Bumi Aksara, 2011.

[9] M. Mulyatun, “Analisis keterampilan dasar mengajar mahasiswa calon guru kimia (Studi pada praktik penglaman lapanagan mahasiswa Tadris kimia)", Jurnal Phenomenon, vol. 4, pp. 79-90, 2014

[10] R. Shavelson, "What is the basic teaching skill?" The Journal of teacher education, vol. 24, 1973.

[11] J.W. Santrock, Educational Psychology. New York: McGraw-Hill, 2018.

[12] AJ. Elliot, A Conceptual History of the Achievement Goal Construct. In J. Elliot \& CS Dweck (ed)., Handbook of Competence and Motivation. New York: Guilford Press. pp 52-72, 2005.

[13] D.H. Schunk, Learning Theories an Educational Perspective. Pearson Education Inc., 2012.

[14] M. Hasan, and R. Sarkar, "Achiement motivation and academic achiement of secondary level students in Uttar Dinajpur District," Research review International Journal of Multidisciplinary, vol. 3, 2018.

[15] R. Bakar, "The effect of learning motivation on student's productive competencies in vocational high scholl West Sumatra," International Journal of Asian Social Science, vol. 4, pp. 722-732, 2014.

[16] D. Djaali, Psikologi Pendidikan. Jakarta: PT Bumi Aksara, 2013. 